\title{
The Routes of Terrorism and Trafficking from Central Asia to Western Europe
}

\section{Brigadier General (Ret.) Russell D. Howard and Colleen M. Traughber}

The difficulty in penetrating Islamist extremist terrorist cells provided the impetus behind the "Routes Project," which is the focus of this issue of Connections. Terrorist cells, particularly those of Al Qaeda and like-minded groups, are difficult to penetrate for a number of reasons. First, Al Qaeda cells are usually well financed, and thus are not susceptible to bribery as a mechanism for gaining access. Second, Al Qaeda training methods prevent those who have not graduated from Al Qaeda camps or other modes of instruction from entering a cell's inner circle. They do not have the correct bona fides and do not know the "secret handshake" that would ensure their trustworthiness. Third, "Al Qaeda is held together by bonds of friendship, kinship, and discipleship," according to Nick Pratt of the George C. Marshall European Center for Security Studies in Garmisch-Partenkirchen. A person can speak the language, look the part, and know the culture, but if he remains an outsider and is not "known" by other Al Qaeda members, he will not be accepted. Fourth, Al Qaeda's complicated cellular structure makes it difficult to effectively penetrate the organization. Its cells operate independently, and each cell leader knows only the person above him in the organization. In addition, one cell leader may command several groups, using one alias with one group and another with a different group, so that captured members of different cells will give interrogators different names. Finally, Islamist terrorist cells do not respond to Cold War-era cell penetration tactics. Bribery (mentioned previously) does not work, nor do drugs, alcohol, or sexual entrapment-penetration mainstays of the competition between the Soviet bloc and the West during the Cold War.

The hypothesis of this project is simple: if terrorist cells resist direct penetration, the next best thing is to take an indirect approach by infiltrating groups that associate and interact with terrorist groups. Thus, the researchers involved in the "Routes Project" examined the linkages between and among terrorist groups and criminal cartels that traffic in drugs, weapons, and people. More specifically, identifying the nexus where terrorist groups converge was deemed most important.

The following assumptions helped frame the project's research:

- Terrorist groups-like traffickers in drugs, weapons, and humans-exploit the "gray areas" where state power is absent or weak, where corruption is rampant, and where the rule of law is nonexistent.

- Terrorist groups and criminal traffickers have different long-term objectives, but they do have a convergence of interests. They all benefit from working in areas characterized by permeable borders, political and economic instability, corruptible officials, and overwhelmed state institutions.

- The most fertile areas to test the project's hypothesis are those where terrorist groups and drug, weapon, and human trafficking groups converge. 
- To date, there is a paucity of pertinent official data on the interrelationships between terrorist and criminal groups, which makes it difficult to establish undeniable and definitive alliances or linkages between and among terrorists and drug, weapon, and human traffickers. However, a simple and common-sense logic suggests that official data collection may provide clearer evidence for such relationships.

The articles included in this issue examine the presence of a "terror-crime nexus" in Central Asia, the South Caucasus, Southeastern Europe, and segments of Western Europe. As a whole, the project specifically focuses on potential points of intersection between terrorism and arms, drug, and human trafficking. First, each piece in the issue outlines the threat that transnational terrorism and international organized crime pose to the states examined. Next, the researchers attempt to determine how, why, and where terrorist and trafficking groups cooperate. Finally, based on the results of the analysis, each article briefly assesses current counterterrorism and counter-trafficking efforts and offers a number of policy recommendations to combat both phenomena in the future.

This project was a year-long effort undertaken by counterterrorism professionals from Azerbaijan, Croatia, Kazakhstan, Moldova, Romania, and the United States. Indeed, the main strength of this project was the people conducting it, all of whom were subject matter experts and volunteers who spent hours collecting and analyzing data on top of busy work schedules and careers. While much was accomplished in determining levels of interaction between terror and crime within the selected regions, the major weakness of the project was the limited number of countries studied. More countries in the Caucasus, the Balkans, Central Asia, and Eastern Europe need to be examined to enhance the validity of the study's findings and to provide more comprehensive conclusions for counterterrorism policymakers.

Each author participating in the study examined a particular region or aspect of the potential terror-crime nexus throughout Central Asia, the South Caucasus, South Eastern Europe, and Western Europe. Summaries of their findings are as follows:

\section{Jahangir Arasli}

In a close analysis of the links between terror and crime in the South Caucasus, Jahangir Arasli investigates the relationship between non-state armed groups and criminal organizations in that region. Focusing on separatist areas, particularly in Azerbaijan and Georgia, he argues that they have essentially become "black holes" of criminality and terrorism. He also points to Iranian control of drugs in the greater Caucasus region - "geo-drugs" - as a potential asymmetrical weapon that could be used against the West. He suggests that the terrorist and criminal activities are entrenched and growing in the South Caucasus, and indicates that the region threatens to replace the Balkans as the preeminent trafficking hub in Eurasia. 


\section{Lucia Vreja}

Focusing on Romania, Dr. Lucia Vreja explores the nexus between terrorism and crime in Southeastern Europe. She details the linkages between terrorist groups and organized crime, which either provide support for each other or benefit from the same regional infrastructure. Further, she identifies the Balkan route as a main path by which traffickers and criminals enter Western Europe. Due to Romania's geographical position along the Balkan route and the relationship of its population to the Middle East, it is at risk for supporting both terrorism and criminal trafficking. As Dr. Vreja suggests, the relationship between terrorism and trafficking is at best blurry.

\section{Colleen M. Traughber}

Colleen M. Traughber's focused study explores the links between terrorism and arms, drug, and human trafficking in the former Soviet republic of Georgia. Using a forwardlooking analytic methodology known as "Preparation of the Investigative Environment" (PIE), she identifies the actual levels of interaction between terrorist and criminal activities. She also acknowledges the indicators of potential collusion between terror and crime in the future. She recognizes the separatist regions as uncontrolled and prospective areas of intersection between terrorist and criminal activity, and points to the general lack of security and atmosphere of weak law enforcement in the Caucasus as a promoter of both terrorism and trafficking.

\section{Rustam Burnashev}

Central Asia is the focus of Dr. Rustam Burnashev's piece, which looks for evidence of terror-crime interaction in the far reaches of Eurasia. Based on the theory of a regional security complex, he considers the weak security situation in Central Asia, which provides a sanctuary for terrorism and all forms of trafficking. Dr. Burnashev identifies Central Asia as being an origin primarily of drugs. Due to the uncontrolled border with Afghanistan, drugs flow freely into Central Asian countries and then on to the West. In comparison to drug trafficking, arms and human trafficking are found to be minor issues in Central Asia.

\section{Krunoslav Antoliš}

Dr. Krunoslav Antoliš investigates terrorist routes in Southeastern Europe and the Balkans - particularly the heart of the routes, which flow from Central Asia to Western Europe. Based out of Croatia, he identifies the routes of migrant, narcotic, and weapons smuggling that course through the former Yugoslavia. The smuggling routes not only significantly overlap with one another, but also provide a conduit for terrorists throughout the region. He argues that the key to combating terrorism and trafficking is both detection and monitoring of the networks' members, and he calls for greater action on the part of national governments to combat the dual problems of terrorism and trafficking. 


\section{Tatiana Busuncian}

Tatiana Busuncian analyzes Moldova's role as a stop along the route of the "instability train" in Southeastern Europe, which runs from Central Asia through the Caucasus and on to the Balkans. Human trafficking is particularly entrenched in Moldova, followed closely by drug smuggling and arms trafficking. In Moldova, there are indications of a mutually beneficial relationship between terrorism and trafficking. The separatist region of Transnistria in Moldova functions as a "gray area," or lawless region conducive to terrorism and trafficking. As such, Moldova is a stop along the Balkan route, the most heavily traveled transit of terrorism and criminality into Western Europe and beyond.

\section{Conclusion}

In summary, the articles in this issue point to the existence of an established nexus between terrorism and organized crime along routes that stretch from Central Asia to Western Europe. Perhaps even more importantly, they suggest that the relationship between terrorism and criminal trafficking in arms, drugs, and humans is entrenched and growing. Given their nature as transnational threats, terrorism and trafficking are increasing as national, regional, and international concerns. Just as the penetration of Islamic extremist terrorist cells is challenging, the penetration of terror-crime conglomerates will prove to be difficult in the future, since the threat is even more mobile and diffuse. However, the possibility of combating terrorism through the penetration of criminal networks - and vice versa - is a promising strategy for the ongoing campaigns against global terrorism and organized crime. 